\title{
Local food, food democracy, and food hubs
}

\author{
Allison Perrett ${ }^{a *}$ and Charlie Jackson ${ }^{\mathrm{b}}$ \\ Appalachian Sustainable Agriculture Project
}

Submitted September 15, 2014 / Revised January 28, April 27, April 30, and May 5, 2015 /

Accepted July 6, 2015 / Published online October 20, 2015

Citation: Perrett, A., \& Jackson, C. (2015). Local food, food democracy, and food

hubs. Journal of Agriculture, Food Systems, and Community Development, 6(1), 7-18.

http://dx.doi.org/10.5304/jafscd.2015.061.003

Copyright (C) 2015 by New Leaf Associates, Inc.

\begin{abstract}
In western North Carolina, where we and others have been working to build local food systems for the last 15 years, food hubs are part of an expanding network of local food distribution infrastructure intended to help the region's smaller local farms access larger, more mainstream market outlets. The impact of food hubs on the region's evolving food system, however, is contradictory. At the same time that food hubs further the development of local food supply chains and create market opportunities for farms, they can also run contrary to the bigger and longer-term goals of the local food movement. In this viewpoint article, we look

a* Corresponding author: Allison Perrett, Local Food Research Center, Appalachian Sustainable Agriculture Project; 306 West Haywood Street; Asheville, North Carolina 28801 USA; +1-828-236-1282 x106; allison@asapconnections.org

b Charlie Jackson, Local Food Research Center, Appalachian Sustainable Agriculture Project; 306 West Haywood Street; Asheville, North Carolina 28801 USA; +1-828-236-1282 x105; charlie@asapconnections.org
\end{abstract}

Author note

The authors are employed by an organization written about in this paper. critically at the role of nonprofit food hubs in efforts to build local food systems. Speaking from our experiences in the local food movement in western North Carolina and drawing from social movements and food systems scholarship, we argue that food hubs, when used as primary mechanisms of local food system building, can deprive the movement of its capacity to activate broad participation in the food system. We argue that efforts to build local food systems need a foundation of work that engages people (such as farmers, citizens, people who work in the food industry) in processes that can shape the practices, values, and impacts of systems of food production and distribution. While they can mitigate the mismatch between the smaller scale typical of local food and larger mainstream markets, food hubs alone cannot challenge industry norms and practices, and they can even aid the food industry in maintaining the status quo.

\section{Keywords}

food democracy, food hubs, local food, social movements, technological fix, western North Carolina 


\section{Introduction}

With the growth of the local food movement nationally, food hubs have emerged as a prominent local food system building strategy (Barham, Tropp, Enterline, Farbman, Fisk, \& Kiraly, 2012; Fischer, Hamm, Pirog, Fisk, Farbman, \& Kiraly, 2013; Matson, Sullins, \& Cook, 2013; Schmit, Jablonski, \& Kay, 2013). Food hub projects are receiving USDA and private grant funding (Barham et al., 2012; Schmit et al., 2013), and they have attracted the attention of big food industry players. Walmart, for example, recently invested US $\$ 3$ million to support efforts to further develop the food hub model (Wallace Center at Winrock International, 2014). In a broad sense, food hubs are a supply chain management strategy and focus on the logistics and distribution of local food. Their organizers attempt to mediate the mismatch between the food industry and the smaller scale of farms and production typical of local food efforts. The authors of a recent report prepared specifically for food industry executives describe food hubs as a means of "solving local" (Cantrell \& Heuer, 2014). As small-farm aggregators, food hubs are able to scale up local food and fit local food into mainstream food supply chains (Cantrell \& Heuer, 2014).

In western North Carolina, where we and others have been working to build local food systems for the last 15 years, food hubs are part of an expanding network of local food distribution infrastructure intended to help local farms access larger, more mainstream market outlets. The impact of food hubs on the region's evolving food system, however, is contradictory. At the same time that food hubs may further the development of local food supply chains, create market opportunities for farms, and increase the availability and visibility of local food, they can also run contrary to the bigger and longer-term goals of the local food movement. They can provide smaller-scale farms struggling to stay economically viable with access to larger-scale market outlets. At the same time, in fitting locally grown food into the existing food industry, food hubs currently are not challenging the way the dominant food industry operates.

In this viewpoint article, with a goal of strengthening what we believe to be a potentially transformative social movement, we look critically at the role of not-for-profit (nonprofit) food hubs in local food system building efforts. If the movement is about challenging the food industry and creating food systems that are socially just, economically fair, and environmentally sustainable, then we-practitioners who are doing the work of local food system building-need to think deeply and critically about the strategies we are using to create change. We use nonprofit food hubs in this paper to critique an approach to local food system building that over focuses on "moving product" rather than on "moving people" in their perspectives and practices. Our perspective is informed by our experiences in the movement in western North Carolina. We also draw from ideas and theories in social movements and food systems scholarship that have helped us think about why and how local food system development can be a catalyst of change and about the strategies that can facilitate that change. With regard to the broader emergence of food hubs in local food efforts across the country, we argue that as a primary strategy of local food system building, food hubs alone cannot challenge industry norms and practices and can even aid the food industry in maintaining the status quo. Local food efforts need a foundation of work that engages people (farmers, ordinary citizens, people that work in the food industry) in processes that can shape the practices, values, and impacts of food production and distribution systems. Reflecting on the trajectory of the movement in western North Carolina, we argue that food hubs have not been the drivers of change but rather have emerged as incremental outcomes of a fundamental and ongoing strategy designed to engage people directly in the development of the region's food system.

To make our argument, we begin by looking at the goals of the local food movement, briefly reviewing the qualities that local food organizers and advocates typically attribute to local food, and a key critique, namely the tendency for local food organizers and supporters to attribute innate qualities to local food. Next, we explore theories and ideas that shed light on the reasons why local food system building in particular can be a path of change. Here, drawing from Hassanein (2003, 
2008), Johnston, Biro, and MacKendrick (2009), and others, we look at local food system development as a strategy that can democratize the food system - that is, activate broad participation to change the food system. We also look at the significance of "place" and of social interaction for activating and mobilizing that participation (Diani, 1997; Escobar, 2001, 2008; Habermas, 1985, 1987; Spinosa, Flores, \& Dreyfus, 1999). From this foundation, in the final section we examine the capacity of nonprofit food hubs to contribute to processes that promote food democracy.

\section{Qualities Attributed to Local Food}

The roots of the movement in western North Carolina go back to 2000, when organizers of a new initiative, Appalachian Sustainable Agriculture Project (ASAP), launched a local food campaignan awareness-raising and community-organizing campaign designed to engage the public with local agriculture, create demand for locally grown food, and build markets for local farms. At the time, our local food campaign was one of a handful in the country in which people were responding to concerns about the loss of farms and farmland and to the decline of rural communities in the context of globalizing markets, changes in federal policy, and food industry consolidation. Organizers of these early campaigns, each located in a region with strong agricultural traditions and relatively small average farm size, aimed to build markets for locally grown food and, through consumer acts of buying local, stem the tide of farm loss.

Fifteen years later, these first campaigns, with innumerable newer campaigns and initiatives around the country, are leading an emergent movement focused on local food system development. What began as a marketing strategy to help farms left out of the dominant food marketplace has grown to be about much more than just supporting farms. Today, movement participants largely conceive of local food as a way of creating environmental, social, and economic sustainability and a path to transforming the food system. As documented in movement and academic literature, food system localization has been associated with a core constellation of qualities and outcomes. ${ }^{1}$ Food produced locally is considered to be more nutritious because it is fresher (i.e., less travel time means more nutrient retention), and increased availability of local food is thought to improve nutrition because greater consumption of fresh fruits and vegetables reduces the incidence of obesity and other health-related problems (Alkon \& Mares, 2012; Allen \& Guthman, 2006; Bagdonis, Hinrichs, \& Schafft, 2009; Cleveland et al., 2011; Ferrer, Fonsah, Ramirez, \& Escalante, 2011; Freedman, 2009; Salois, 2012). Local food is assumed to be more environmentally sustainable: closer production/consumption relationships mean fewer food miles, less reliance on fossil fuels, and smaller-scale farms purportedly use more ecologically sound production practices (Clancy, 2015; Goodman \& Goodman, 2007; Lockie \& Halpin, 2005; Norberg-Hodge, Merrifield, \& Gorelick, 2002; Pirog, 2004). Moreover, local food systems are understood to have the capacity to strengthen local economies (Allen \& Hinrichs, 2007; Halweil, 2002; LaTrobe, 2001; Meter, 2011; O'Hara, 2011; Swenson, 2008, 2011; Tregear, 2011) and create market transparency through close production/ consumption linkages and the development of community relationships and engaged consumers (Allen, FitzSimmons, Goodman, \& Warner, 2003; Allen \& Hinrichs, 2007; Johnston, Biro, \& MacKendrick, 2009; Kloppenburg, Hendrickson, \& Stevenson, 1996; Perrett, 2013).

While these qualities are typically attributed to local food, as Allen and Hinrichs (2007), Born and Purcell (2006), Johnston et al. (2009), and others have argued, they are not inherent to local food, and there is a tendency among local food movement supporters to assume that local food by virtue of being local has intrinsic, beneficent qualities. Born and Purcell (2006) have described this tendency as the "local trap," the assumption that local by nature of its scale is inherently more sustainable and just. Other critics have also cautioned against this assumption, noting that the proximity of food sourcing does not equate automatically to other attributes such as energy efficiency (e.g., Schlich \&

\footnotetext{
${ }^{1}$ Authors are not necessarily supporting claims but documenting them.
} 
Fleissner, 2005; Wallgren, 2006), environmentally sustainable production practices (e.g., Goodman \& Goodman, 2007; Hinrichs, 2003), fair labor practices (e.g., Belliveau, 2005, as cited in Johnston et al., 2009, p. 515), social justice (e.g., Allen \& Guthman, 2006; Allen \& Hinrichs, 2007; DeLind, 2002; Hinrichs \& Allen, 2008), or engaged citizens (e.g., DeLind, 2002; Guthman, 2008; Johnston, 2008). In a recent column, Clancy (2015), writing about the difficulty people have in accepting new evidence when it challenges pre-existing ideas and beliefs, takes this critique a step further. Drawing on local food as an example, she argues that even with evidence that has refuted the claim that local food is more energy efficient (assumed because foods are produced closer to the point of consumption), the claim is nevertheless still made. A key point we make in this paper is that we need to carefully scrutinize our strategies so that we are not undermining the potential of local food system building efforts to create the qualities and conditions we imagine are possible.

In the next section, we look at why local food system building can be a strategy for achieving the theorized qualities and outcomes of local food. We draw from the idea of food democracy to explore the importance of opening food system practices and values to citizen reflection and meaningful debate. We draw from perspectives that look at the significance of "place" in modern movements to explore the role local food system building efforts can play in activating this kind of participation and creating spaces for public discussion around food and agriculture.

\section{How and Why Local Food System Building Can Be a Catalyst of Food System Change}

Since the inception of the local food campaign in western North Carolina in 2000, our organization's strategies have focused on engaging consumers and people who work in the food industry in the region directly with local food and farms through things like farmers markets, community supported agriculture operations (CSAs), local food and farm fairs, farm tours, farm-to-school activities, and food and agricultural conferences. Before local food gained its current popularity, when local food was a relatively new idea, these types of activities were conceived as a way to "put a face on food." This phrase is commonly used by staff in our organization to describe the significance of direct interaction with farmers, farms, and food growing locally for embedding decisions around food and eating in local relationships. As the movement has continued to unfold and evolve (and with that, our thinking and understanding), we have come to see how vital these local food and farm venues are for facilitating social interaction, and that social interaction is vital to effecting food system change. Social interaction provides the space for dialogue among and between farmers, consumers, and food industry people around food and farming in the region - the space for farmers to share information about their farms and products, their business and production practices, and the realities of farming, and for consumers and food industry personnel to learn and ask questions about farming in the region and express their concerns or desires for food produced in particular ways. From our perspective, these conversations are vital, because they enable people who live and work here to actively participate in the region's food system and guide the direction of its development.

In the food systems literature, scholars talk about the significance of food system participation for creating food system change. Hassanein (2003) argues that conflicts over food production and food industry practices are fundamentally about values and the types of practices these values legitimize. Without our participation as citizens, we allow others to define those values for us, and currently we have a food system that is concentrated in the hands of a few large corporations with disproportionate control over the way food is produced and distributed. Local food initiatives are looked at as a way to move toward food democracy (Hassanein, 2003, 2008; Johnston et al., 2009; Levkoe, 2006). In alignment with the qualities attributed to local food, food democracy is a concept that describes systems of food production that produce nutritious, safe food in ways that are environmentally sustainable and that provide fair access to land and fair wages to those who labor in the food system (Hassanein, 2008; Johnston et al., 2009). These qualities and conditions are created through processes that lay bare food industry 
practices and relations of production, empower people to shape the values, policies, practices, and outcomes of food production systems, and liberate food production from corporate control (Johnston et al., 2009). Creating food democracy is about people coming to actively participate in the food system, not remaining "passive spectators" (Hassanein, 2003, p. 79; Welsh \& MacRae, 1998). Thus food democratizing efforts create spaces where producers and consumers "can act as citizens" (Johnston et al., 2009, pp. 514-515) where individuals are able to gain knowledge about food and the food system, share their ideas and opinions about the food system with other people, and, with an increased capacity, exercise their power to shape the ways food is produced and distributed (Hassanein, 2008; Levkoe, 2006). As argued by Johnston et al. (2009), without processes that engage people in the food system, countermovements like the local food movement lose their transformative potential, and "local food"-in keeping with the local food trap critique-becomes yet another label in the marketplace with assumed qualities and characteristics (Delind, 2011).

This perspective, that changing the food system requires a broadening of citizen participation and that local food is a means to do that, raises an important question: what is it about local food specifically that lends itself to this process? The answer has a direct bearing on the kinds of strategies we use to mobilize and sustain participation in the movement and is relevant to our assessment of food hubs. Scholars looking at the importance of "place" and at the realm of everyday ordinary life to modern social movements provide insight into the change-making potential of local food system building efforts. In social movements, "place" is important to the emergence of collective action because particular places are where specific economies, ecologies, and social practices are located and, as such, they are also the sites of struggle around them (Escobar, 2001). In relation to a dominant global economic system, place is the position from which we observe and experience adverse impacts to our livelihoods and communities, and to the landscapes and ecosystems of which we are a part (Escobar, 2001, 2008). Spinosa, Flores, and Dreyfus (1999) have argued that cultural innovation and the impulse to act in ways that challenge taken-for-granted cultural norms emerge not from positions of detachment but from a deep connectedness with or rootedness in the conditions and particularities of place. As sites of human experience and where we live our day-today lives, place is the position from which we encounter discrepancies between accepted, shared frameworks of meaning and our lived realities, and it is where we imagine and engage in new ways of being (Spinosa et al., 1999, pp. 22-24). The realm of everyday life (where we carry out mundane daily activities like shopping, eating, cooking, cleaning, working, interacting, etc.) is where we affirm and reproduce predominant ways of living and the ideas that underlie them, or resist them through the enactment of different ideas and ways of living (Escobar, 1992a, 1992b; Melucci, 1985, 1989; Perrett, 2013). Escobar (1998, 2008), drawing on his long-term study of a social movement in Colombia, points to the importance of everyday life for social movements for the space that it provides for social interaction. Social interaction is what nurtures and gives rise to collective action because it provides the space for collective reflection on current realities and the development of shared understandings, values, and goals (Escobar, 1998, 2008).

The importance of social interaction for the emergence of collective action and for democracy is not a new idea; it has been looked at by numerous scholars (Coleman, 1988; Diani, 1997; Paxton, 2002; Putnam, 1995, 2001; Woolcock, 1998; Woolcock \& Narayan, 2000). Diani (1997), looking specifically at how movements achieve outcomes, argues that the ability of social movement organizations to affect change depends directly upon their capacity to reproduce existing social ties and generate new ones. He argues that community linkages are both preconditions and products of collective action, and that social ties among movement and potential movement constituents are necessary to mobilize and sustain movement activity. Habermas (1985, 1987, 2000 as cited in Randall, 2008), writing about conditions in the current stage of capitalism, discusses the loss of "public spheres" or spaces where members of a community can come together to interact, discuss 
matters of public importance, develop mutual understandings, and work toward shared goals. With this loss and with the help of a corporately controlled media, Habermas argues that instrumental rationality, a logic grounded in capitalism and focused on the most cost effective means of achieving an end, has replaced a communicative rationality, one grounded in and guided by interpersonal interaction and reasoned discussion.

We think these ideas have enormous relevance for the work of local food system building efforts. If we come from the idea that democratizing the food system is going to be crucial to challenging and changing it, then actions that facilitate that process become important. Local food, because it is anchored in the particularities of place (in local people, resources, and relationships), offers a means to connect consumers in meaningful ways with food and agriculture and heighten their awareness and understanding of food and agricultural issues. ${ }^{2}$ If, as Diani suggests, social movements depend on social interaction to mobilize participation and effect change, then the loss of public spheres has implications for movement actions and suggests the importance for organizers to create spaces that facilitate the flow of information and ideas and foster discussion.

In western North Carolina, the local food movement emerged from a deeply rooted perspective-from the lived experiences of a group of residents and farmers and their shared understanding that, without some kind of intervention, farming as a way of life could not survive in the wake of an increasingly dominant global economic system. "Local food" was the strategy early organizers conceptualized as a way to deeply root the public in a place where farming was important to its history, landscape, and culture. Farm tours, farmers markets, and the like were conceived by organizers as ways to meaningfully engage the public with local agriculture, build community ties centered on local food and agriculture, and link decisions around food and eating to a growing appreciation for local farms and a desire to

\footnotetext{
2 We do not mean to imply that local food is the only way to build democracy in the food system, but that it is uniquely positioned to do so for the reasons outlined.
}

preserve them.

Fifteen years later, at ASAP we also work directly with the buyers for larger-scale grocer, restaurant, and institutional markets to build local food supply chains - in some cases directly between farmers and these buyers, and in others by engaging the wholesalers in the region, for-profit distributors and packers and nonprofit food hubs. The base of our work, however, continues to focus on actions that provide members of the public as well as people that work in the food industry in the region with direct food and farm experiences. In western North Carolina, engagement strategies provide the foundation for the development of a shared belief that local farms are important to the region's economy and to our quality of life. They are the foundation of consumer interest and demand from markets that are part of the conventional food industry. And they have contributed to the emergence of other kinds of nonmarket movement activity, for example, the development of food policy councils, the actions of parents to challenge and change school nutrition services, the food, farm, and nutrition education programs of universities and colleges, and increasing public discussion around food access and food justice. Without this groundwork of engagement, we argue food hubs risk helping the food industry reduce "local food" to just another product in the marketplace.

\section{Food Hubs and Food Democracy}

In western North Carolina, the local food procurement strategies of many of the region's larger mainstream market outlets, including larger grocery chains and institutions (schools, hospitals, and colleges), use nonprofit food hubs to source locally grown food. Echoing a pattern dominant in the food industry, the larger food companies in this region want to source from a small pool of large suppliers year round and at a price achieved through economies of scale, i.e., through the cost savings that come from spreading out fixed costs over larger volumes. But locally grown food in western North Carolina is predominantly seasonal, the region's farms are small by national standards, and food production here is not easily scalable to high-volume production. In contrast to food pro- 
duced for the conventional food industry, local food production is the purview of many smaller farms; the scale of production is smaller and decentralized, with limited infrastructure for aggregation, distribution, and processing. Food hubs serve as or aim to serve as market intermediaries to bridge mainstream markets and smallerscale farms. They provide buyers in the food industry in the region with volumes needed and with required quality standards and safety assurances, and they save buyers the time and energy that would be required to source directly from multiple farms (Perrett, 2013).

The effect of food hubs on the region's evolving food system is complicated. Food hubs do provide a piece of aggregation and distribution infrastructure that helps connect smaller farms to larger scale markets, thus providing the region's farms with more market opportunities (and potentially more needed income), getting more locally grown food into more places, and increasing its availability beyond direct-to-consumer markets. At the same time, however, nonprofit food hubs as market intermediaries do not fundamentally challenge the principles and practices on which the food industry operates.

As a particular model of local food aggregation and distribution, nonprofit food hubs use grants and other outside funding to mediate between markets where large-volume production determines conventional prices and the smaller-scale production by farmers who produce at higher costs (LeBlanc, Conner, McRae, \& Darby, 2014; Local Food Research Center, 2012). To mediate this disparity, nonprofit food hubs subsidize the higher cost of local food production and distribution to meet the price points expected by the food industry. Beyond the potential ameliorative role nonprofit hubs might play in connecting locally grown food to mainstream markets, ${ }^{3}$ nonprofit

\footnotetext{
${ }^{3}$ How effective nonprofit hubs can be at fulfilling this intermediary role remains to be seen. LeBlanc et al. (2014) note that dependence on outside funding for continued operation threatens the long-term financial viability of nonprofit food hubs. And after assessing 15 years of food hub development and practice in California, Community Alliance with Family Farmers (CAFF) concludes that as a strategy for local food system development, food hubs are not viable; they
}

food hubs-conceived as infrastructure to solve a barrier to the entry of locally grown food into mainstream markets ${ }^{4}$ - can become a kind of "technological fix" (Scott, 2011). The technological fix concept is one that is commonly used in public debates surrounding science and technology and their contributions to solving human problems (Scott, 2011). Technological fix strategies cast problems as being technological and thus solvable through technological innovation (Scott, 2011). ${ }^{5}$ In his examination of the technological fix concept in relation to agricultural biotechnology, Scott (2011) points out that the appeal of this kind of problemsolving approach is that it provides a means to simplify potentially complicated social problems and define clear courses of action. The limitation, however, is technological fixes do not address the root causes of problems and often create new ones, even if unintentionally. Rather than fostering people's abilities to critically question and examine the system (i.e., the ideas and presumptions that produce social problems), technological fixes draw attention away from root causes, thereby delaying examination and action and perhaps compounding problems (Scott, 2011).

When conceived as a means of "fixing" supply chain barriers to locally grown food and providing farmers with access to new markets at prevailing market price points, nonprofit food hubs simply reinforce that status quo. They do not facilitate, and may even impede, fundamental challenges to the food industry. In their reliance on grants and other outside support to help cover their operating costs, nonprofit hubs are able to sell their products below what it costs to produce and distribute them. In western North Carolina, according to reports from some farmers and food distributors, non-

\footnotetext{
add extra costs to supply chains, duplicate and compete with existing regional distribution infrastructure, and struggle financially without ongoing subsidy support (Abellera, Signore, Derden-Little, Michas, Runsten, \& Sabato, 2014).

${ }^{4}$ Some food hubs have goals related to increasing access by low-income consumer to locally grown foods (e.g., LeBlanc et al., 2014). The 2013 National Food Hub Survey indicates that food hubs with social goals make up a small minority of the total (Fischer et al., 2013).

${ }^{5}$ Technological innovation can refer to machinery and equipment as well as to processes and methods.
} 
profit food hubs have had the unintended consequence of undercutting and taking business from for-profit local food distributors and/or farmers not using outside funds to subsidize their businesses. Unintentional as it may be, this strategy arguably functions similarly to a tactic common in the agro-food industry, namely cross-subsidization: using resources from other enterprises to sell products below cost and gain greater market share by both pushing competitors out of the market and discouraging new competitors (Heffernan, 2000). A recent report on food value chains alludes to the "market distortion" that operations like food hubs can produce through their reliance on subsidies. This distortion can be significant in that it creates in the minds of food industry buyers unrealistic expectations about price and puts unsubsidized operations at a disadvantage in the marketplace by undercutting the actual costs of production (Diamond, Tropp, Barham, Muldoon, Kiraly, \& Cantrell, 2014).

Despite this critique, the intent of this article is not to wholly dismiss food hubs as a local food system building strategy. Our intent is to examine them critically in relation to the aspirations of movement activists and supporters, and in relation to ideas about how we can create the substantive change we want to see. In western North Carolina, food hubs are part of a food system that is in transition. Their presence points to the degree to which local food has captured the interest of the public (and, following, the market) and the degree to which movement ideas and practices are rubbing up against the entrenched ideas and practices of the food industry. At the same time, food hubs are emerging in a context of continuing farm loss. In this context, our organization struggles to balance actions that address the immediate situation - the need to slow or stop continuing farm decline-and actions grounded in a larger and longer term perspective- the need to fundamentally change the way that we as farmers, consumers, people who work in the food industry, etc., think about and relate to food, eating, and agriculture. Mediating between these two needs, our organization works with farmers, nonprofit food hubs, for-profit aggregators and distributors, and mainstream markets to build local food supply relationships (to provide the region's smaller-scale farms with market opportunities they need to stay viable, continue farming, and keep their land out of development) alongside engagement-based strategies centered around farms, local food, and movement participants. Without local farms there is no agricultural base to engage with or affect. Without strategies that engage people with local farms and food and other movement participants, we participate in a process that continues to alienate people from the food system and from processes that enable them to guide the direction of the movement and the formation of the region's food system. That these strategies co-exist in western North Carolina is a crucial point. Fifteen years ago, "local food" was a new concept. The movement had not begun. Demand from mainstream markets did not exist. The degree to which food hubs are an aspect of the region's developing local food system today is in large part the outcome of 15 years of local food campaign activity that at its core has focused on strategies to engage people in activities that raise awareness of problems and solutions surrounding the social, economic, and environmental issues that intersect with food systems. Food hubs have not been the drivers of food system change; they are provisional and incremental outcomes of an underlying effort that is striving to engage people directly in the development of a food system, to participate democratically in a process that informs what it looks like and how it operates.

Today the context for emerging local food initiatives is vastly different than it was in 2000: local food is a national movement. Awareness of and demand for local food is emerging not only from place-based local food campaigns, but also from a larger national discussion stimulated by stories in national media outlets, popular books (e.g., Pollan's The Omnivore's Dilemma) and documentaries (e.g., Food, Inc.), prominent movement figures (e.g., Mark Bittman, Michael Pollan, Joel Salatin), and from the increasing prevalence of local food messaging in national grocery store chains. The movement has become popular, and this popularity is fueling both the 
growth of the market for locally grown food ${ }^{6}$ and the interest in starting local food-based initiatives in communities and regions across the country. The result is that "local food" is now a known concept to many people and has a developed market presence. In this context, food hubs that are emerging as primary mechanisms of local food system building, in response to local food market opportunities, can deprive the movement of its transformative potential for fostering food system democracy. We believe local food efforts need a foundation of engagement that broadly activates people in the work of defining how food systems operate, and the values and principles on which food system practices are based, and that gives rise to place-based ideas and innovations to solve the problems (Lyson, 2005) of local food distribution. Based on what we have learned from 15 years of local food system building work and from research we conduct to evaluate the impacts of our strategies, ${ }^{7}$ we believe that engagement-based strategies are what move people in their perceptions and actions around food and eating and agriculture, and that this kind of movement, in keeping with the idea of food system democratization, is the foundation of meaningful food system change. Without this foundation, food hubs can merely become an instrument of the food industry to "fix" local food, using the rhetoric of "local" while reducing it to a geographic characteristic, and undermining the larger, more difficult, and longerterm project that broadens participation to shape the food system.

\section{References}

Abellera, D., Signore, D. D., Derden-Little, E., Michas, A., Runsten, D., \& Sabato, M. (2014). Making the invisible visible: Looking back at fifteen years of local food systems distribution solutions. Community Alliance with

\footnotetext{
${ }^{6}$ According to USDA figures, local food sales increased from nearly US $\$ 5$ billion in 2008 to US $\$ 7$ billion in 2012 (USDA, 2013).

${ }^{7}$ ASAP's Local Food Research Center studies the processes and outcomes of the region's localizing food system. Using the framework outlined in this paper, we are developing indicators and measures of food system democratization to understand and document the effects of engagement-based strategies on people.
}

Family Farmers. Retrieved from http://caff.org/ wp-content/uploads/2010/07/CAFF-LessonsLocal-Distribution-102814.pdf

Alkon, A. H., \& Mares, T. M. (2012). Food sovereignty in US food movements: Radical visions and neoliberal constraints. Agriculture and Human Values, 29(3), 347-359. http://dx.doi.org/10.1007/s10460012-9356-Z

Allen, P., FitzSimmons, M., Goodman, M., \& Warner, K. (2003). Shifting plates in the agrifood landscape: The tectonics of alternative agrifood initiatives in California. Journal of Rural Studies, 19(1), 61-75. http://dx.doi.org/10.1016/S0743-0167(02)00047-5

Allen, P., \& Guthman, J. (2006). From "old school" to "farm-to-school": Neoliberalization from the ground up. Agriculture and Human Values, 23(4), 401-415. http://dx.doi.org/10.1007/s10460-006$\underline{9019-Z}$

Allen, P., \& Hinrichs, C. (2007). Buying into 'buy local': Engagements of United States local food initiatives. In D. Maye, M. Kneafsey \& L. Holloway (Eds.), Alternative food geographies (pp. 255-272). Oxford: Elsevier.

Bagdonis, J. M., Hinrichs, C., \& Schafft, K. A. (2009). The emergence and framing of farm-to-school initiatives: Civic engagement, health and local agriculture. Agriculture and Human V alues, 26(1), 107-119. http://dx.doi.org/10.1007/s10460-0089173-6

Barham, J., Tropp, D., Enterline, K., Farbman, J., Fisk, J., \& Kiraly, S. (2012). Regional food bub resource guide. Washington, D.C.: USDA Agricultural Marketing Service. Retrieved from http://www.ams.usda. gov/sites/default/files/media/Regional Food Hub Resource Guide.pdf

Belliveau, S. (2005). Resisting global, buying local: Goldschmidt revisited. Great Lakes Geographer, 12(1), 45-53.

Born, B., \& Purcell, M. (2006). Avoiding the local trap. Journal of Planning Education and Research, 26(2), 195207. http://dx.doi.org/10.1177/0739456X06291389

Cantrell, P., \& Heuer, B. (2014). Food hubs: Solving local: Small-farm aggregators scale up with larger buyers. Wallace Center at Winrock International. Retrieved from http://www.ngfn.org/resources/ngfndatabase/knowledge/Food Hubs - Solving Local.pdf 
Clancy, K. (2015). Another argument for adaptability. Journal of Agriculture, Food Systems, and Community Development, 5(2), 7-10. http://dx.doi.org/10.5304/jafscd.2015.052.007

Cleveland, D. A., Radka, C. N., Muller, N. M., Watson, T. D., Rekstein, N. J., Wright, H. V. M., \& Hollingshead, S. E. (2011). Effect of localizing fruit and vegetable consumption on greenhouse gas emissions and nutrition, Santa Barbara County. Environmental Science \& Technology, 45(10), 45554562. http://dx.doi.org/10.1021/es1040317

Coleman, J. (1988). The creation and destruction of social capital: Implications for the law. Notre Dame Journal of Law, Ethics, and Public Policy, 3, 375-404.

DeLind, L. (2002). Place, work, and civic agriculture: Common fields for cultivation. Agriculture and Human Values, 19(3), 217-224. http://dx.doi.org/10.1023/A:1019994728252

DeLind, L. (2011). Are local food and the local food movement taking us where we want to go? Or are we hitching our wagons to the wrong stars? Agriculture and Human Values, 28(2), 273-283. http://dx.doi.org/10.1007/s10460-010-9263-0

Diamond, A., Tropp, D., Barham, J., Muldoon, M. F., Kiraly, S., \& Cantrell, P. (2014). Food value chains: Creating shared value to enhance marketing success. Washington, D.C.: United States Department of Agriculture, Agricultural Marketing Service.

Diani, M. (1997). Social movements and social capital: A network perspective on movement outcomes. Mobilization: An International Quarterly, 2(2), 129-147.

Escobar, A. (1992a). Culture, economics, and politics in Latin American social movements theory and research. In A. Escobar \& S. E. Alvarez (Eds.), The making of social movements in Latin America: Identity, strategy, and democracy (pp. 62-88). Boulder: Westview Press.

Escobar, A. (1992b). Culture, practice and politics: Anthropology and the study of social movements. Critique of Anthropology, 12(4), 395-432. http://dx.doi.org/10.1177/0308275X9201200402

Escobar, A. (1998). Whose knowledge, whose nature? Biodiversity, conservation, and the political ecology of social movements. Journal of Political Ecology, 5, 53-82.

Escobar, A. (2001). Culture sits in places: Reflections on globalism and subaltern strategies of localization. Political Geography, 20(2), 139-174.
http://dx.doi.org/10.1016/S0962-6298(00)00064-0

Escobar, A. (2008). Territories of difference: Place, movements, life, redes. Durham, North Carolina: Duke University Press Books. http://dx.doi.org/10.1215/9780822389439

Ferrer, M. C. R., Fonsah, E. G., Ramirez, O., \& Escalante, C. L. (2011). Local food impacts on health and nutrition. Paper presented at the Agricultural and Applied Economics Association's AAEA \& NAREA Joint Annual Meeting, Pittsburgh, Pennsylvania.

Fischer, M., Hamm, M., Pirog, R., Fisk, J., Farbman, J., \& Kiraly, S. (2013). Findings of the 2013 National Food Hub Survey. Michigan State University Center for Regional Food Systems and The Wallace Center at Winrock International. Retrieved from http://kresge.org/sites/default/files/2013national-food-hub-survey.pdf

Freedman, D. A. (2009). Local food environments: They're all stocked differently. American Journal of Community Psychology, 44(3), 382-393. http://dx.doi.org/10.1007/s10464-009-9272-6

Goodman, D., \& Goodman, M. (2007). Localism, livelihoods and the 'post-organic': Changing perspectives on alternative food networks in the United States. In D. Maye, L. Holloway, \& M. Kneafsey (Eds.), Alternative Food Geographies (pp. 2338). Oxford: Emerald Publishing Group.

Guthman, J. (2008). Neoliberalism and the making of food politics in California. Geoforum, 39(3), 11711183. http://dx.doi.org/10.1016/i.geoforum.2006.09.002

Habermas, J. (1985). The theory of communicative action: Reason and the rationalization of society, Volume 1 ( $T$. McCarthy, Trans.). Boston: Beacon Press.

Habermas, J. (1987). The theory of communicative action: Lifeworld and system: A critique of functionalist reason, Volume 2 (T. McCarthy, Trans.). Boston: Beacon Press.

Habermas, J. (2000). On the pragmatics of communication. Cambridge, Massachusetts: The MIT Press.

Halweil, B. (2002). Home grown: The case for local food in a global market (Worldwatch Paper No. 163). Washington, D.C.: Worldwatch Institute.

Hassanein, N. (2003). Practicing food democracy: A pragmatic politics of transformation. Journal of Rural Studies, 19(1), 77-86.

http://dx.doi.org/10.1016/S0743-0167(02)00041-4 
Hassanein, N. (2008). Locating food democracy: Theoretical and practical ingredients. Journal of Hunger \& Environmental Nutrition, 3(2-3), 286-308. http://dx.doi.org/10.1080/19320240802244215

Heffernan, W. D. (2000). Concentration of ownership and control in agriculture. In F. Madgoff, J. B. Foster, \& F. H. Buttel (Eds.), Hungry for profit: The agribusiness threat to farmers, food, and the environment (pp. 61-75). New York: Monthly Review Press.

Hinrichs, C. C. (2003). The practice and politics of food system localization. Journal of Rural Studies, 19(1), 33-45. http://dx.doi.org/10.1016/S07430167(02)00040-2

Hinrichs, C. C., \& Allen, P. (2008). Selective patronage and social justice: Local food consumer campaigns in historical context. Journal of Agricultural and Environmental Ethics, 21(4), 329-352. http://dx.doi.org/10.1007/s10806-008-9089-6

Johnston, J. (2008). The citizen-consumer hybrid: Ideological tensions and the case of Whole Foods Market. Theory and Society, 37(3), 229-270. http://dx.doi.org/10.1007/s11186-007-9058-5

Johnston, J., Biro, A., \& MacKendrick, N. (2009). Lost in the supermarket: The corporate-organic foodscape and the struggle for food democracy. Antipode, 41(3), 509-532. http://dx.doi.org/ 10.1111/i.1467-8330.2009.00685.x

Kloppenburg, J., Hendrickson, J., \& Stevenson, G. W. (1996). Coming in to the foodshed. Agriculture and Human Values, 13(3), 33-42. http://dx.doi.org/10.1007/BF01538225

LaTrobe, H. (2001). Farmers' markets: Consuming local rural produce. International Journal of Consumer Studies, 25(3), 181-192. http://dx.doi.org/10.1046/j.14706431.2001.00171.x

LeBlanc, J. R., Conner, D., McRae, G., \& Darby, H. (2014). Building resilience in nonprofit food hubs. Journal of Agriculture, Food Systems, and Community Development, 4(3), 121-135. http://dx.doi.org/10.5304/jafscd.2014.043.005

Levkoe, C. Z. (2006). Learning democracy through food justice movements. Agriculture and Human Values, 23(1), 89-98. http://dx.doi.org/10.1007/s10460005-5871-5

Local Food Research Center. (2012). Non-profit food hubs: Summary of economic viability. Asheville, North Carolina: Appalachian Sustainable Agriculture
Project. Retrieved from http://asapconnections. org/downloads/asap-summary-of-economicviability-non-profit-food-hubs.pdf

Lockie, S., \& Halpin, D. (2005). The 'conventionalisation' thesis reconsidered: Structural and ideological transformation of Australian organic agriculture. Sociologia Ruralis, 45(4), 284-307. http://dx.doi.org/10.1111/j.1467-9523.2005. 00306.x

Lyson, T. A. (2005). Civic agriculture and community problem solving. Culture and Agriculture, 27(2), 9298. http://dx.doi.org/10.1525/cag.2005.27.2.92

Matson, J., Sullins, M., \& Cook, C. (2013). The role of food bubs in local food marketing. Washington, D.C.: USDA. Retrieved from http://www.rd.usda.gov/files/sr73.pdf

Melucci, A. (1985). The symbolic challenge of contemporary movements. Social Research: $A n$ International Quarterly, 52(4), 789-816.

Melucci, A. (Author), Keane, J., \& Mier, P. (Eds.). (1989). Nomads of the present: Social movements and individual needs in contemporary society. Philadelphia: Temple University Press.

Meter, K. (2011). Obio's food systems - Farms at the heart of it all. Minneapolis: Crossroads Resource Center.

Norberg-Hodge, H., Merrifield, T., \& Gorelick, S. (2002). Bringing the food economy home: Local alternatives to global agribusiness. London: Zed Books.

O’Hara, J. K. (2011). Market forces: Creating jobs through public investment in local and regional food systems. Cambridge, Massachusetts: Union of Concerned Scientists.

Paxton, P. (2002). Social capital and democracy: An interdependent relationship. American Sociological Review, 67(2), 254-277. http://dx.doi.org/10.2307/3088895

Perrett, A. S. (2013). Cultivating local: Building a local food system in Western North Carolina (Doctoral dissertation). University of South Florida, Tampa.

Pirog, R. (2004). Food miles: A simple metaphor to contrast local and global food systems. Ames, Iowa: Leopold Center for Sustainable Agriculture.

Putnam, R. D. (1995). Bowling alone: America's declining social capital. Journal of Democracy, 6(1), 6578. http://dx.doi.org/10.1353/jod.1995.0002

Putnam, R. D. (2001). Bowling alone: The collapse and revival of American community. New York: Simon and Schuster. 
Randall, D. (2008). Ethos, poetics, and the literary public sphere. Modern Language Quarterly, 69(2), 221243. http://dx.doi.org/10.1215/00267929-2007$\underline{033}$

Salois, M. J. (2012). Obesity and diabetes, the built environment, and the "local" food economy in the United States, 2007. Economics and Human Biology 10 (1), 35-42. http://dx.doi.org/10.1016/j.ehb.2011.04.001

Schlich, E. H., \& Fleissner, U. (2005). The ecology of scale: Assessment of regional energy turnover and comparison with global food. International Journal of Life Cycle Assessment, 10, 219-223.

Schmit, T. M., Jablonski, B. B. R., \& Kay, D. (2013). Assessing the economic impacts of regional food hubs: The case of regional access. Ithaca, New York: Cornell University.

Scott, D. (2011). The technological fix criticisms and the agricultural biotechnology debate. Journal of Agricultural and Environmental Ethics, 24(3), 207-226. http://dx.doi.org/10.1007/s10806-010-9253-7

Spinosa, C., Flores, F., \& Dreyfus, H. (1999). Disclosing new worlds: Entrepreneurship, democratic action, and the cultivation of solidarity. Cambridge, Massachusetts: The MIT Press.

Swenson, D. (2008). Estimating the production and market value-based impacts of nutritional goals in NE Iowa. Ames, Iowa: Leopold Center for Sustainable Agriculture.

Swenson, D. (2011). Exploring small-scale meat processing expansions in Iowa. Ames, Iowa: Leopold Center for Sustainable Agriculture.
Tregear, A. (2011). Progressing knowledge in alternative and local food networks: Critical reflections and a research agenda. Journal of Rural Studies, 27(4), 419430. http://dx.doi.org/10.1016/i.jrurstud.2011.06.003

U.S. Department of Agriculture [USDA]. (2013). USDA celebrates national farmers market week, August 410. Confirms growth and sustainability in farmers markets [Press release]. Retrieved from http://www.usda.gov/wps/portal/usda/usdahome ?contentid $=2013 / 08 / 0155 . x \mathrm{xl}$

Wallace Center at Winrock International. (2014). Wallace Center expands food hub program. Wallace Center Updates January 2014 Newsletter.

Wallgren, C. (2006). Local or global food markets: A comparison of energy use for transport. Local Environment, 11(2), 233-251. http://dx.doi.org/10.1080/13549830600558598

Welsh, J., \& MacRae, R. (1998). Food citizenship and community food security: Lessons from Toronto, Canada. Canadian Journal of Development Studies, 19(4), 237-255. http://dx.doi.org/10.1080/02255189.1998.9669786

Woolcock, M. (1998). Social capital and economic development: Toward a theoretical synthesis and policy framework. Theory and Society, 27(2), 151-208. http://dx.doi.org/10.1023/A:1006884930135

Woolcock, M., \& Narayan, D. (2000). Social capital: Implications for development theory, research, and policy. The World Bank Research Observer, 15(2), 225249. http://dx.doi.org/10.1093/wbro/15.2.225 